\title{
Pengaruh Metode Bermain Peran Makro terhadap Peningkatan Kemampuan Berbicara Anak
}

\author{
DESI SUKENTI* \\ TETIN TRISNAWATI**
}

\author{
*Fakultas Keguruan dan Ilmu Pendidikan (FKIP) Universitas Islam Riau (UIR) Pekanbaru \\ Jl. Kaharuddin Nasution, No. 113, Perhentian Marpoyan, Pekanbaru \\ e-mail: dsukenti@rocketmail.com. HP: 081371539122 \\ **Sekolah Tinggi Keguruan dan Ilmu Pendidikan Aisyiyyah Riau \\ Jl. Angkasa Pekanbaru
}

\begin{abstract}
Abstrak: Anak-anak merupakan generasi penerus bangsa. Oleh karena itu, dalam suatu bangsa harus mempersiapkan masa depan anak-anak melalui pendidikan yang tepat. Pendidikan tidak hanya sebagai kegiatan pentrasferan ilmu akan tetapi juga pengembangan karakter dan kemampuan diri anak. Kemampuan untuk bersosialisasi dan mengemukakan pendapat secara lisan merupakan kemampuan yang wajib dikembangan dari dalam diri anak. Salah satu metode yang dipergunakan dalam pendidikan untuk mengembangkan kemampuan berbicara dan bersosialisasi anak adalah metode bermain peran. Penelitian ini fokus terhadap investigasi pada pengaruh metode bermain peran makro terhadap kemampuan berbicara anak. Ini adalah merupak penelitian eksperimen, sedangkan pengumpulan data dalam penelitianju ini adalah observasi dengan menggunakan skala-skala yang akan mengukur kemampuan berbicara anak. Data yang diperoleh dianalisis menggunakan SPSS 17,0. Hasil penelitian menunjukkan bahwa terdapat pengaruh yang signifikan dari penggunaan metode bermain peran makro terhadap peningkatan kemampuan berbicara anak usia 5-6 tahun di Taman Kanak-Kanak Negeri Pembina 2 Pekanbaru.
\end{abstract}

Kata kunci: pendidikan, metode bermain peran makro, kemampuan berbicara anak.

\section{PENDAHULUAN}

Pendidikan merupakan modal dasar untuk menyiapkan insan yang berkualitas. Menurut Undang-Undang Sistem Pendidikan Nasional adalah usaha sadar dan terencana untuk mewujudkan suasana belajar dan proses pembelajaran agar peserta didik secara aktif mengembangkan potensi dirinya untuk memiliki kekuatan spiritual keagamaan, pengendalian diri, kepribadian, kecerdasan, akhlak mulia, serta keterampilan yang diperlukan untuk dirinya, masyarakat, bangsa dan negara. Pada hakikatnya belajar harus berlangsung sepanjang hayat. Untuk menciptakan generasi yang berkualitas, 
pendidikan harus dilakukan sejak usia dini dalam hal ini melalui Pendidikan Anak Usia Dini (PAUD), yaitu pendidikan yang ditujukan bagi anak sejak lahir hingga usia 6 tahun.

Anak usia dini merupakan individu yang berbeda, unik, dan memiliki karakteristik tersendiri sesuai dengan tahapan usianya. Masa usia dini (0-6 tahun) merupakan masa keemasan (golden age), yang mana pada masa ini stimulasi seluruh aspek perkembangan berperan penting untuk tugas perkembangan selanjutnya. Perlu disadari bahwa masa-masa awal kehidupan anak merupakan masa terpenting dalam rentang kehidupan seseorang anak. Pada masa ini pertumbuhan otak sedang mengalami perkembangan yang sangat pesat.

Mengingat pentingnya masa ini, maka peran stimulasi berupa penyediaan lingkungan yang kondusif harus disiapkan oleh para pendidik, baik orang tua, guru, pengasuh ataupun orang dewasa lain yang ada di sekitar anak, sehingga anak memiliki kesempatan untuk mengembangkan seluruh potensinya. Potensi yang dimaksud meliputi aspek nilai agama dan moral, sosial-emosional dan kemandirian, kemampuan berbahasa, kognitif, dan fisik/motorik. Pendidikan anak usia dini diberikan pada awal kehidupan anak untuk dapat berkembang secara optimal.

Dalam berkomunikasi, berbicara merupakan alat yang penting bagi setiap orang. Melalui berbicara seseorang atau anak akan dapat mengembangkan kemampuan bergaul dengan orang lain. Penguasaan keterampilan bergaul dalam lingkungan sosial dimulai dengan penguasaan kemampuan berbicara. Tanpa bahasa seseorang tidak akan dapat berkomunikasi dengan orang lain. Anak dapat mengekspresikan pikirannya menggunakan bahasa sehingga orang lain dapat menangkap apa yang dipikirkan oleh anak. Komunikasi antar anak dapat terjalin baik sehingga anak dapat membangun hubungan interaksi social dengan lingkungan sekitarnya.Dengan demikian tidak mengherankan bahwa bahasa dianggap sebagai salah satu indikator kesuksesan seorang anak. Anak yang dianggap banyak berbicara atau banyak bertanya merupakan cerminan anak yang cerdas.

Salah satu aspek perkembangan yang ingin dicapai oleh anak usia dini adalah aspek kemampuan berbicara (bahasa). Kemampuan ini memberikan gambaran tentang kesanggupan anak menyusun berbagai kosa kata yang telah dikuasai menjadi suatu rangkaian pembicaraan secara berstruktur. Misalnya kemampuan anak mengulang kembali penjelasan ataupun pembicaraan yang telah didengarnya dengan menggunakan kata-kata atau kalimat yang sesuai sehingga dapat dimengerti oleh orang lain. Maka dari itu diperlukan latihan, praktek serta pembiasaan yang rutin (Anwar,2006:6).

Untuk mewujudkan kemampuan berbicara anak dapat dilakukan dengan penerapan berbagai metode yang salah satunya adalah metode bermain peran makro. Metode bermain peran makro adalah cara mengajar yang memberikan kesempatan kepada anak didik untuk mendramatisasikan sikap, tingkah laku dan penghayatan seseorang.

Salah satu sarana untuk dapat saling berhubungan adalah dengan menggunakan bahasa yang dapat diwujudkan melalui percakapan atau berbicara. Atas dasar kenyataan tersebut, maka dapat disusun kerangka pemecahan masalah secara rasional bahwa proses pembelajaran bermain peran sesuai dengan teori tersebut, dapat meningkatkan kemampuan anak untuk berbicara. Anak didik diberi 
contoh konkrit dan dilibatkan langsung dalam proses pembelajaran serta diberi kesempatan untuk memerankan dirinya sendiri maupun orang lain dalam aktivitas berbicara.

Oleh karena itu, peneliti tertarik untuk melakukan suatu penelitian sebagai upaya dalam melakukan perbaikan terhadap hasil pembelajaran dengan judul "Pengaruh Metode Bermain Peran Makro Terhadap Peningkatan Kemampuan Berbicara Anak Usia 5-6 Tahun di Taman Kanak-Kanak Negeri Pembina 2 Pekanbaru".

Penelitian ini bertujuan untuk Untuk mengetahui apakah terdapat pengaruh metode bermain peran makro terhadap peningkatan kemampuan berbicara anak usia 5-6 tahun di Taman Kanak-Kanak Negeri Pembina 2 Pekanbaru. Disamping itu, penelitian ini bermanfaat secara teoritis dan praktis. Secara teoritis, diperoleh pengetahuan yang sangat berharga secara teori tentang bermain peran makro dan kemampuan berbicara anak dari kepustakaan dan fakta empiris dilapangan khususnya mengenai peningkatan kemampuan berbicara anak melalui penerapan metode bermain peran makro. Sedangkan secara praktis, penelitian ini bermanfaat bagi guru (pendidik) sebagai acuan dalam penerapan metode bermain peran makrountuk meningkatkan kemampuan berbicara anak usia 5-6 tahun di TK Negeri Pembina 2 Pekanbaru dan bagi anak, penelitian ini diharapkan dapat meningkatkan kemampuan berbicara anak usia 5-6 tahun di TK Negeri Pembina 2 Pekanbaru.

\section{KONSEP TEORI}

\section{Hakikat Metode Bermain Peran}

Nurbiana Dhieni (2006:7.31) mengatakan bahwa metode bermain peran dikategorikan sebagai metode mengajar yang berumpun kepada metode perilaku yang diterapkan dalam pengajaran.Karakteristiknya adalah adanya kecenderungan memecahkan tugas belajar dalam sejumlah perilaku yang berurutan, konkret dan dapat diamati.

Menurut Roestiyah (2001:90) metode bermain peran dinyatakan sebagai suatu jenis teknik simulasi yang umumnya digunakan untuk pendidikan sosial dan hubungan antar insan. Teknik ini mengajak anak untuk dapat mendramatisasikan tingkah laku atau ungkapan gerak-gerik wajah seseorang dalam hubungan sosial antar manusia atau anak bisa berperan atau memainkan peranan dalam dramatisasi masalah sosial atau psikologis.

Selanjutnya pengertian bermain peran menurut Yuliani dan Bambang(2010:81) adalah kegiatan yang berfokus pada kegiatan dramatisasi, tempat anak-anak bermain untuk memerankan tugas-tugas anggota keluarga, tata cara dan kebiasaan dalam keluarga dengan berbagai perlengkapan rumah tangga serta kegiatan dilingkungan sekitarnya.

Winda Gunarti (2008:10.9) menyatakan bahwa bermain peran adalah memerankan karakter atau tingkah laku dalam pengulangan kejadian yang diulang kembali, kejadian masa depan, kejadian masa kini atau situasi imajinatif.

Selanjutnya Winda Gunarti (2008:10.10) peran diartikan sebagai suatu rangkaian perasaan, ucapan dan tindakan individu yang ditujukan kepada orang lain. Peran seseorang dalam kehidupan dipengaruhi oleh persepsi dan penilaian oleh dirinya dan orang lain. Untuk dapat berperan dengan baik, diperlukan pemahaman tentang peran itu sendiri mencakup apa yang tampak dan tindakan yang tersembunyi dalam perasaan, persepsi 
dan sikap. Esensi bermain peranditujukan untuk membantu individu dalam memahami perannya sendiri dan peran yang dimainkan orang lain sekaligus memahami perasaannya sendiri dan peran yang dimainkan orang lain sekaligus berupaya memahami perasan dan sikap yang mendasarinya.

Menurut Ahmadi (2005:80) mengemukakan bahwa metode bermain peran disebut juga 'sosiodrama' yaitu suatu cara mengajar yang memberikan kesempatan kepada para anak untuk mendramatisasikan sikap, tingkah laku atau penghayatan seseorang, seperti yang dilakukan dalam hubungan sosial sehari-hari dalam masyarakat. Dalam proses bermain peran peserta diminta untuk: (a) Mengandaikan suatu peran khusus, apakah sebagai mereka sendiri atau sebagai orang lain; (b) Masuk dalam situasi yang bersifat skenario, yang dipilih berdasarkan relevansi dengan pengetahuan yang sedang dipelajari oleh peserta atau kurikulum; (c) Bertindak persis sebagaimana pandangan mereka terhadap orang yang diperankan dalam situasi-situasi tertentu ini, dengan menyepakati untuk bertindak seolah-olah peran-peran tersebut adalah peran-peran mereka sendiri dan bertindak berdasar asumsi tersebut; dan (d) Menggunakan pengalaman-pengalaman peran yang sama pada masa lalu untuk mengisi batas yang hilang dalam suatu peran singkat yang ditentukan.

Menurut Sudjana (2005:85)

menambahkan bahwa dengan cara mengajar dengan bermain peran, para anak diberi kesempatan dalam menggambarkan, mengungkapkan atau mengekspresikan suatu sikap, tingkah laku atau penghayatan sesuatu yang dipikirkan, dirasakan, atau diinginkan seandainya ia menjadi tokoh yang sedang diperankannya itu, yang penting diingat ialah semua tugas yang diserahkan kepada anak harus dilaksanakan sewajar-wajarnya jangan berlebihan. Semua sikap dan tingkah laku hendaknya diungkapkan secara spontan, itulah sebabnya para pelaku suatu peranan tidak memerlukan teks kata-kata atau kalimatyang sudah disiapkan terlebih dahulu. Mereka cukup memahami garis-garis besar apa yang akan didramatisasikan.

Menurut Zaini

(2007:101)

berpendapat bahwa bermain peran adalah suatu aktivitas pembelajaran yang terencana yang dirancang untuk mencapai tujuan-tujuan pendidikan yang spesifik. Bermain peran berdasar pada tiga aspek utama dari pengalaman peran dalam kehidupan sehari-hari: (a) Mengambil peran (Role-taking), yaitu: tekanan ekspektasi-ekspektasi sosial terhadap pemegang peran, contoh: berdasar pada hubungan keluarga (apa yang harus dikerjakan anak perempuan) dalam situasi sosial; (b) Membuat peran (Role-making), yaitu: kemampuan pemegang peran untuk merubah secara dramatis dari satu peran ke peran yang lain dan menciptakan serta memodifikasi peran sewaktu-waktu diperlukan; dan (c) Tawar-menawar peran (Role-negotiotion), yaitu: tingkat dimana peran-peran dinegosiasikan dengan pemegang-pemegang peran yang lain dalam parameter dan hambatan interaksi sosial.

Selanjutnya, Nana (2005:85) juga mengemukakan bahwa tujuan bermain peran antara lain: (1) Agar anak dapat menghayati dan menghargai perasaan orang lain; (2) Dapat belajar bagaimana membagi tanggung jawab; (3) Dapat belajar bagaimana mengambil keputusan dalam situasi kelompok secara spontan; dan (4) Merangsang kelas untuk berfikir dan memecahkan masalah.

Berdasarkan pendapat-pendapat diatas dapat disimpulkan bahwa metode 
bermain peran adalah suatu cara mengajar yang memberikan kesempatan kepada anak untuk mendramatisasikan sikap, tingkah laku atau penghayatan seseorang, seperti yang dilakukan dalam hubungan sosial sehari-hari. Dengan kata lain melalui metode bermain peran ini anak belajar untuk menghargai perasaan orang lain dan belajar untuk bekerjasama dengan orang lain.

\section{Jenis-Jenis Metode Bermain Peran} Menurut Diana Mutiah (2010:115) ada dua jenis bermain peran, yaitu mikro dan makro. Bermain peran mikro adalah kegiatan dimana anak memegang atau menggerakgerakkan benda-benda berukuran kecil untuk menyusun adegan. Seperti anakanak belajar menjadi sutradara, memainkan boneka, dan mainan berukuran kecil seperti rumahrumahan, kursi sofa mini, tempat tidur mini (seperti bermain boneka barbie). Biasanya mereka akan menciptakan percakapan sendiri. Sedangkan bermain peran makro adalah anak berperan sesungguhnya dan menjadi seseorang atau sesuatu. Saat anak memiliki pengalaman sehari-hari dengan main peran makro (tema sekitar kehidupan nyata), mereka belajar banyak keterampilan seperti anak berperan menjadi seseorang yang mereka inginkan. Bisa mama, papa, tante,polisi, sopir, dan pilot.

Saat bermain peran ini bisa menjadi ajang belajar bagi mereka, baik belajar membaca, berhitung, mempelajari proses/alur dalam mengerjakan sesuatu, mengenal tata tertib/tata cara di suatu tempat, yang semua ada dalam kehidupan kita. Tentu saja kita hanya cukup memberikan informasi sebelum mereka mulai bermain, dan atau lebih baik kalau kita terlibat dalam permainan tersebut agar kita bisa menggali imajinasi dan mengenalkan informasi yang ingin kita kenalkan.

\section{Langkah-Langkah Metode Bermain Peran}

$\begin{array}{ccr}\text { Seperti } & \text { telah } & \text { dipaparkan } \\ \text { sebelumnya, } & \text { setiap } & \text { metode }\end{array}$ pembelajaran memiliki langkah-langkah tertentu yang memberikan kekhasan terhadap metode itu sendiri. Nurbiana Dhieni (2006:7.34)menyatakan bahwa langkah-langkah metode bermain peran sebagai berikut : (1) Guru menyiapkan naskah, alat media dan kostum yang akan digunakan dalam kegiatan bermain peran; (2) Guru menerangkan teknik bermain peran dengan cara yang sederhana; (3) Guru memberikan kebebasan bagi anak untuk memilih peran yang disukainya; (4) Jika bermain peran untuk pertama kali dilakukan, sebaiknya guru sendiri memilih siswa yang kiranya dapat melaksanakan tugas itu; (5) Guru menetapkan peran pendengar (anak didik yang tidak turut melaksanakan tugas tersebut); (6) Guru menetapkan dengan jelas masalah dan peranan yang mereka harus mainkan; (7) Guru menyarankan kalimat pertama yang baik diucapkan oleh pemain untuk memulai; (8) Guru menghentikan bermain peran pada detik-detik situasi sedang memuncak dan kemudian membuka diskusi umum; dan (9) Sebagai hasil diskusi kadang-kadang dapat meminta kepada anak untuk menyelesaikan masalah itu dengan caracara lain.

\section{Hakikat Berbicara Anak}

Berbicara dapat diartikan suatu penyampaian maksud seseorang kepada orang lain dengan menggunakan bahasa lisan sehingga maksud tersebut dapat dipahami oleh orang lain. Manusia 
berbicara dengan memanfaatkan faktor fisik, psikologis, neurologis, semantik dan linguistik (Suhartono, $2005: 44$ ).

Kemudian Nurbiana Dhieni (2006:3.9) menyatakan bahwa pada anak usia TK (4-6 tahun) kemampuan berbahasa anak yang paling efektif adalah kemampuan berbicara. Hal ini selaras dengan karakteristik umum kemampuan bahasa anak pada usia tersebut. Kemampuan ini meliputi kemampuan anak untuk dapat berbicara dengan baik, melaksanakan tiga perintah lisan secara berurutan dengan benar, mendengarkan dan menceritakan kembali cerita sederhana dengan urutan yang mudah dipahami, menyebutkan nama, jenis kelamin dan umurnya, menggunakan kata sambung seperti dan, karena, tetapi, menggunakan kata tanya seperti bagaimana, apa, mengapa, kapan, membandingkan dua hal, memahami konsep timbal balik, menyusun kalimat, mengucapkan lebih dari tiga kalimat, dan mengenali tulisan sederhana.

Lebih lanjut (Suhartono, 2005 :22) menyatakan bahwa berbicara anak adalah suatu penyampaian maksud tertentu dengan mengucapkan bunyibunyi bahasa supaya bunyi tersebut dapat dipahami oleh orang yang ada dan mendengar disekitarnya,hampir semua bunyi yang di ucapkan anak mempunyai maksud tertentu,walaupun bunyi tersebut bukan bunyi berbentuk kata maupun kalimat. Jadi yang di maksud bicara anak lebih luas maknanya dengan makna berbicara.Jika berbicara lebih di artikan sebagai pengucapan bunyi-bunyi bahasa yang dapat di pahami oleh lawan bicara,tetapi bicara anak lebih di artikan bunyi yang di ucapkan oleh anak baik bunyi bahasa maupun bunyi-bunyi bukan bahasa tetapi di ucapkan oleh alat ucap anak.

Berbicara merupakan suatu aktivitas yang dilakukan oleh semua orang untuk menyampaikan pesan atau maksud kepada orang lain. Berbicara merupakan salah komponen kemampuan dalam berbahasa.

Lebih lanjut Henry (2008:1-3) setiap keterampilan itu, berhubungan erat sekali dengan tiga keterampilan lainnya dengan cara yang beraneka ragam. Dalam memperoleh keterampilan berbahasa, biasanya kita melalui suatu hubungan urutan yang teratur, mula-mula pada masa kecil kita belajar menyimak bahasa, kemudian berbicara, sesudah itu kita belajar membaca dan menulis. Menyimak dan berbicara kita pelajari sebelum memasuki sekolah. Keempat keterampilan tersebut pada dasarnya suatu kesatuan.

Sedangkan berbicara adalah suatu keterampilan berbahasa yang berkembang pada kehidupan anak, yang hanya didahului oleh keterampilan menyimak, dan pada masa tersebutlah kemampuan berbicara atau berujar dipelajari. Berbicara sudah barang tentu berhubungan dengan perkembangan kosa kata yang diperoleh oleh sang anak melalui kegiatan menyimak dan membaca.

Mustafa dan Lana (1986:3) menyatakan bahwa berbicara adalah menyampaikan maksud (ide, isi hati serta pikiran) seseorang kepada orang lain dengan menggunakan bahsa lisan sehingga maksud tersebut dipahami oleh orang lain. Depdiknas (2007:15) mengemukakan bahwa kemampuan berbicara merupakan kemampuan anak untuk berkomunikasi secara lisan dengan orang lain. Kemampuan ini memberikan gambaran tentang kesanggupan anak menyusun berbagai kosa kata yang telah dikuasai menjadi suatu rangkaian pembicaraan secara berstruktur.

Berdasarkan kajian teori di atas, maka dapat dijelaskan bahwa berbicara 
adalah suatu proses penyampaian pesan (ide-ide atau gagasan, maksud) dari seseorang kepada orang lain dalam bentuk bunyi bahasa. Dengan kata lain berbicara tidak hanya sebatas pengucapan bunyi-bunyi atau kata-kata. Berbicara adalah suatu alat untuk mengkomunikasikan gagasan-gagasan yang disusun serta dikembangkan sesuai dengan kebutuhan-kebutuhan sang pendengar. Bila seseorang dapat menyampaikan ide atau pikirannya pada orang lain sehingga orang lain mengerti apa yang dibicarakannya, maka orang tersebut memiliki kemampuan berbicara yang baik.

Bila dicermati kemampuan berbicara pada anak usia dini tersebut di atas, diketahui bahwa anak telah mulai dilatih untuk berbicara atau berkomunikasi agar mereka dapat dapat berinteraksi dengan yang lainnya. Melalui kemampuan ini anak dapat menyampaikan pesan-pesan atau menerima pesan dari orang lain. Sehubungan dengan penelitian ini, maka dalam membahas tentang kemampuan berbicara anak dibatasi pada satu aspek saja yaitu anak dapat mnggunakan dan dapat menjawab pertanyaan apa, berapa, dimana, mengapa dan bagaimana secara sederhana. Hal ini dilakukan mengingat keterbatasan yang dimiliki oleh penulis dan waktu yang tersedia.

\section{Tahap-tahap Berbicara Anak \\ Perkembangan}

Menurut Syakir, Abdul Azim (2002:41) menyatakan bahwa fase-fase perkembangan anak merupakan rangkaian yang berkesinambungan. Setiap rangkaian diikuti dan disempurnakan oleh rangkaian diikuti dan disempurnakan oleh rangkaian berikutnya. Bahasa anak usia dua tahun didominasi oleh pemakaian kata benda, karena secara umum mereka lemah dalam pemakaian verba, kata depan dan kata sarana transpormatif. Tatkala fase ini berakhir, berangsur-angsur anak memasuki fase pemakaian kalimat yang pendek yang terdiri dari tiga hingga lima kata. Ketika anak berusia empat tahun dia mampu membuat kalimat yang terdiri atas enam hingga delapan kata. Fase ini ditandai dengan penentuan jumlah kata dalam sebuah kalimat dan kompleksitasnya

Dhieni

mengemukakan bahwa ketika anak tumbuh dan berkembang, terjadi peningkatan baik dalam hal kuantitas maupun kualitas bahasa. Secara bertahap kemampuan anak meningkat, berawal dari mengekspresikan suara saja, hingga mengekspresikan dengan komunikasi. Komunikasi anak yang bermula dengan menggunakan gerakan dan isyarat untuk menunjukkan keinginannya secara bertahap berkembang menjadi komunikasi melalui ucapan yang tepat dan jelas. Hal ini dapat terlihat sejak awal perkembangan dimana bayi mengeluarkan bunyi "ocehan" yang kemudian berkembang menjadi sistem simbol bunyi yang bermakna.

Vygotsky (dalam Rita Kurnia, 2009:47) menjelaskan tiga tahap perkembangan bicara anak yang berhubungan erat dengan perkembangan berpikir anak yaitu: (1) Tahap eksternal, terjadi ketika anak berbicara eksternal di mana sumber berpikir berasal dari luar diri anak. Sumber berpikir berasal dari orang dewasa yang memberikan pengarahan atau informasi. Sumber berfikir ini sebagian besar berasal dari orang dewasa yang memberikan pengarahan, informasi dan melakukan tanya jawab dengan anak. Sebagai contoh orang dewasa bertanya: "Kamu sedang apa?" anak menjawab," Sedang makan”, orang 
dewasa tersebut lalu meneruskan pertanyaannya,"Mana sendoknya", dan seterusnya; (2) Tahap egosentris, dimana anak berbicara sesuai dengan jalan pikirannya dan pembicaraan orang dewasa bukan lagi menjadi prasyarat; dan (3) Tahap internal, dimana dalam proses berpikir anak telah memilki penghayatan sepenuhnya.

Untuk dapat mengelompokkan jenis-jenis kegiatan atau aktivitas, maka diperlukan suatu sudut pandang yang sama untuk memperoleh pandangan yang sama pula terhadap suatu definisi, begitu juga halnya dengan berbicara.

Nurbiana Dhieni (2006:3.4) mengemukakan bahwa ada dua tipe perkembangan berbicara anak: yaitu egosentric speech dan socialized speech. Egosentric speech terjadi ketika anak berusia 2 - 3 tahun, dimana anak berbicara pada dirinya sendiri (monolog). Perkembangan berbicara anak dalam hal ini sangat berperan dalam mengembangkan kemampuan berpikirnya. Sedangkan Socialized speech terjadi ketika anak berinteraksi dengan temannya ataupun lingkungannya. Hal ini berfungsi untuk mengembangkan kemampuan adaptasi sosial anak. Berkenaan dengan hal tersebut terdapat 5 bentuk Socialized speech, yaitu: (1) Saling tukar informasi untuk tujuan bersama, (2) Penilaian terhadap ucapan atau tingkah laku orang lain, (3) Perintah, permintaan dan ancaman, (4) Pertanyaan dan (5) Jawaban.

\section{Kemampuan Berbicara Anak Usia Dini}

Salah satu aspek perkembangan yang ingin dicapai oleh anak usia dini adalah aspek kemampuan berbicara. Kemampuan ini diperlukan sebagai dasar bagi anak untuk berkomunikasi dengan orang lain, baik dengan teman seusianya maupun dengan orang lebih dewasa dari segi umurnya.

Tarigan

mengemukakan bahwa berbicara adalah suatu ketrampilan berbahasa yang berkembang pada kehidupan anak, yang hanya didahului oleh keterampilan menyimak, dan pada masa tersebutlah kemampuan berbicara atau berujar dipelajari. Berbicara sudah barang tentu erat berhubungan dengan perkembangan kosa kata yang diperoleh oleh anak melalui kegiatan menyimak dan membaca. Kebelum matangan dalam perkembangan bahasa juga merupakan suatu keterlambatan dalam kegiatan-kegiatan berbahasa. Juga perlu disadari bahwa ketrampilanketrampilan yang diperlukan bagi kegiatan berbicara yang efektif banyak persamaannya dengan yang dibutuhkan bagi komunikasi efektif dalam ketrampilan-ketrampilan berbahasa lainnya.

Santosa, dkk (2006:3.7) menyatakan bahwa berbicara adalah mengungkapkan gagasan dan perasaan, menyampaikan sambutan, berdialog, menyampaikan pesan, bertukar pengalaman, menjelasakan, mendeskripsikan dan tanya jawab. Berbicara merupakan keterampilan berbahasa yang produktif. Keterampilan ini sebagai implementasi dari hasil simakan. Peristiwa ini berkembang pesat pada kehidupan anak-anak. Hal itu tampak dari penambahan kosa kata yang disimak anak dari lingkungan semakin hari semakin bertambah pula.

Berdasarkan pendapat-pendapat yang telah dipaparkan, maka dapat ditarik suatu kesimpulan bahwa berbicara adalah suatu proses penyampaian pesan (ide-ide atau gagasan, maksud) dari seseorang kepada orang lain dalam bentuk bunyi bahasa. Dengan kata lain berbicara tidak hanya sebatas pengucapan bunyi-bunyi 
atau kata-kata. Berbicara adalah suatu alat untuk mengkomunikasikan gagasan-gagasan yang disusun serta dikembangkan sesuai dengan kebutuhan-kebutuhan sang pendengar.

Bila dicermati kemampuan berbicara pada anak usia dini tersebut di atas, diketahui bahwa anak telah mulai dilatih untuk berbicara atau berkomunikasi agar mereka dapat dapat berinteraksi dengan yang lainnya. Melalui kemampuan ini anak dapat menyampaikan pesan-pesan atau menerima pesan dari orang lain. Suhartono

(2005:21)

menyatakan bahwa pada saat berbicara seseorang akan memanfaatkan fisiknya yaitu alat ucap untuk menghasilkan bunyi bahasa. Bahkan organ tubuh yang lain seperti kepala, tangan dan roman muka pun dimanfaatkan dalam berbicara. Faktor psikologis memberikan andil yang cukup besar terhadap kelancaran berbicara. Stabilitas emosi misalnya tidak saja berpengaruh terhadap kualitas suara yang dihasilkanoleh alat ucap tetapi juga berpengaruh terhadap keruntutan bahan pembicaraan. Sedangkan

menurut

Permendiknas No. 58 (2009: 10) menyatakan bahwa indikator kemampuan berbicara (kemampuan mengungkapkan bahasa) anak usia 5-6 tahun adalah: (a) Menjawab pertanyaan tentang keterangan/informasi; (b) Menggunakan dan dapat menjawab pertanyaan apa, mengapa, dimana, berapa, dsb; (c) Berani bertanya secara sederhana; (d) Menceritakan pengalaman/kejadian secara sederhana; (e) Memberikan keterangan/informasi tentang sesuatu hal; (f) Bercerita menggunakan kata ganti aku, saya, kamu, dia, mereka; (g) Mau mengungkapkan pendapat secara sederhana; dan (g) Mendengarkan dan menceritakan kembali cerita secara urut.

\section{Kerangka Pemikiran}

Kerangka berpikir adalah pola pikir penelitian mengenai pelaksanaan penelitian, yang bermula ditemukannya permasalahan di lapangan tentang kemampuan berbicara anak yang masih rendah, serta bagaimana caranya meningkatkan kemampuan berbicara anak yang masih rendah itu menjadi meningkat. Dengan ditemukannya permasalahan tersebut, peneliti ingin melakukan suatu upaya untuk membantu permasalahan tersebut.

Penelitian ini bertujuan untuk meningkatkan kemampuan berbicara anak usia 5-6 tahun yang masih kurang. Disini peneliti menggunakan tindakan melalui bermain peran makro. Dengan bermain peran, anak akan diberi kesempatan untuk menggambarkan, mengungkapkan atau mengekspresikan suatu sikap, tingkah laku atau penghayatan sesuatu yang dipikirkan, dirasakan, atau diinginkan seandainya ia menjadi tokoh yang sedang diperankannya itu.Dalamhalini anak dapat mengekspresikan gerakan dan dapat mengendalikan emosinya, bisa menunjukkan rasa marah, takut, senang dan gembira.

Hal ini dapat memberikan pengaruh yang positif terhadap kemampuan berbicara anak.Kemampuan berbicara anak terkait dengan kepandaian untuk melihat sesuatu dari sudut pandang orang lain. Kecerdasan ini menuntun seseorang untuk memahami, bekerjasama, dan berkomunikasi, serta memelihara hubungan baik dengan orang lain. Dengan begitu, kemampuan berbicara anak secara perlahan akan 
meningkat.Beranjak dari pemikiran tersebut, maka peneliti berasumsi bahwa dengan metode bermain peran makro diterapkan akan mampu meningkatkan kemampuan berbicara anak di TK Negeri Pembina 2 Pekanbaru.

\section{METODE}

penelitian ini dilaksanakan di Taman Kanak-Kanak Negeri Pembina 2 Pekanbaruyang beralamat di Jl. Soekarno-HattaKomplek Perumahan Damai Langgeng Pekanbaru. Penelitian ini menggunakan metode PreExsperimental.Karena desain ini belum merupakan eksperimen sungguhsungguh.Mengapa?Karena masih terdapat variabel luar yang ikut berpengaruh terhadap terbentuknya variabel dependen.Jadi hasil eksperimen yang menjadi variabel dependen itu bukan semata-mata dipengaruhi oleh variabel independen.Hal ini dapat terjadi, karena tidak adanya variabel control, dan sampel tidak dipilih secara random.(Sugiyono, 2013:74).

Teknik pengumpulan data dalam penelitian ini adalah observasi. Guna dari observasi adalah untuk melihat fenomena yang unik dan menarik untuk dijadikan fokus penelitian yaitu untuk melihat Pengaruh Metode Bermain Peran MakroTerhadap Peningkatan KemampuanBerbicara Anak Usia 5-6 Tahun di Taman Kanak-Kanak Negeri Pembina 2 Pekanbaru.Kemudian mengadakan pertimbangan dan dimasukkan kedalam suatu penilaian.

Dalam design ini hanya terdapat satu kelompok yang tidak dipilih secara random sebagai Kelompok Eksperimen (KE).Kelompok Eksperimen diberi treatment/perlakuan (X) dan dilakukan pengukuran setelah diberi treatment. Ekperimen dilakukan sebanyak dua kali untuk melihat apakah ada pengaruh treatment yang diberikan terhadap peningkatan kemampuan berbicara anak.

Penelitian ini dilaksanakan di Taman Kanak-Kanak Negeri Pembina 2 Pekanbaru. Didalam skenario eksperimen ini peneliti akan memaparkan/menjelaskan langkahlangkah ataupun alur dari bermain peran yang akan dieksperimenkan. Ada dua judul cerita dari naskah dialog bermain peran makro yang disiapkan oleh peneliti, yaitu: Pertama, Naskah dialog berjudul "Berlibur Ke Kebun Binatang”. Sebelum melakukan kegiatan bermain peran, peneliti terlebih dahulu mempersiapkan segala sesuatu yang dibutuhkan sebagai alat/media pendukung untuk bermain peran. Kegiatan bermain beran ini akan dilaksanakan didalam kelas yang sudah disetting sesuai kebutuhan. Langkah pertama peneliti membacakan naskah dialog didepan anak-anak yang sudah duduk dengan rapi dan siap untuk mendengarkan alur cerita yang akan diperankan. Selanjutnya peneliti menjelaskan aturan bermain secara teknis dengan penjelasan yang mudah dimengerti oleh anak. Didalam naskah bermain peran ini diceritakan bahwa sebentar lagi siswa/i di TK Negeri Pembina II akan libur akhir semester. Mereka menyambut dengan antusias kabar gembira tersebut. Adapun Tokohtokoh yang ada didalam cerita ini diantaranya : (a) Fajar sebagai salah satu murid di TK Negeri Pembina II; (b) Ibu sebagai orang tua dari Fajar; (c) Ayah sebagai orang tua dari Fajar; (d) Annisa sebagai adik dari Fajar; dan (e) Penjual tiket.

Setelah diberikan penjelasan dan dibacakan naskah dialog tersebut, peneliti meminta beberapa anak untuk memerankan tokoh seperti yang ada dalam cerita sebagai simulasi awal. Masuk kepada tahap berikutnya peneliti 
memberikan kebebasan kepada setiap anak untuk memilih perannya masingmasing sesuai karakter dan kemampuannya dalam bermain peran. Dari 10 siswa yang diekperimen diambil 5 orang yang akan bermain peran otomatis ada sisa 5 orang yang menjadi penonton (peran pendengar). Peran pendengar ini akan mendapatkan giliran bermain peran yang sama. Peneliti memberikan kebebasan kepada setiap anak untuk dapat mengembangkan/mengimprovisasi baik dari segi bahasa maupun ekpresi supaya dapat mendalami karakter peran yang dimainkan. Dengan catatan tetap menggunakan bahasa Indonesia yang baik dan benar.

Setelah selesai melaksanakan kegiatan bermain peran peneliti memberikan tes kepada anak dengan menjawag beberapa pertanyaan yang telah dipersiapkan oleh peneliti berupa lembar observasi. Adapun jumlah item pertanyaan yang dibuat sebanyak 25 item, dengan kriteria penilain 1) Bulat penuh artinya anak mampu menjawab pertanyaan dengan tepat tanpa bantuan, 2) Bulat setengah penuh artinya anak mampu menjawab dengan sedikit bantuan, dan 3) Bulat kosong artinya anak tidak mampu menjawab pertanyaan. Berdasarkan kriteria penilaian diatas skor untuk bulat penuh adalah 3, bulat setengah penuh 2 dan bulat kosong 1 . Penilaian diambil dengan cara menceklis kolom sesuai kemampuan anak dalam menjawab pertanyaan yang sudah disusun oleh peneliti.
Kedua, naskah dialog berjudul "Hadiah Dari Kantor Papa". Skenario ekperimen pada kedua ini hampir sama dengan skenario pertama. Pelaksanaan bermain peran tetap didalam kelas dengan settingan yang berbeda sesuai dengan kebutuhan dalam cerita.Didalam naskah menceritakan tentang seorang ayah yang mendapatkan hadiah sebuah rumah dari kantornya, karena prestasi kerjanya yang baik dan memiliki pengabdian yang tinggi terhadap perusahaannya. Tokoh-tokoh yang ada dalam cerita ini adalah: (a) Papa sebagai karyawan kantor; (b) Mama; (c) Pipi sebagai anak dari Papa dan Mama; (d) Karyawan SPBU; dan (e) Penjual bensin dipinggir jalan.

Dalam pengambilan data tersebut peneliti dibantu oleh seorang asisten peneliti. Penilaian diambil seperti pada skenario pertama sesuai ketentuan yang sudah dibuat pada lembar observasi.Anak-anak terlihat antusias saat melakukan peran yang mereka mainkan.Meskipun ada beberapa anak yang biasa-biasa saja saat kegiatan ini berlangsung.

Instrumen penelitian ini berupa skala yang disusun berdasarkan Permendiknas No.58 Tahun 2009. Skala dibuat 2 buah yang bersifat setara (Linear).Skala pertama disebut Skala Kemampuan Berbicara I dan skala kedua disebut Skala Kemampuan Berbicara II. Adapun butir skala tersebut dapat dilihat pada Blue Print dibawah ini :

Tabel 3.1

Skala Kemampuan Berbicara I

\begin{tabular}{clc}
\hline No & \multicolumn{1}{c}{ Indikator } & Item \\
\hline 1 & Menjawab pertanyaan tentang keterangan / informasi & $1,2,3,4$ \\
\hline 2 & $\begin{array}{l}\text { Menggunakan dan dapat menjawab pertanyaan apa, } \\
\text { mengapa, dimana, berapa, dsb. }\end{array}$ & $5,6,7,8,9$ \\
\hline 3 & Berani bertanya secara sederhana & 10,11 \\
\hline
\end{tabular}




\begin{tabular}{clc}
\hline 4 & Menceritakan pengalaman/ kejadian secara sederhana. & $12,13,14$ \\
\hline 5 & Memberikan keterangan/ informasi tentang sesuatu hal & $15,16,17$ \\
\hline & $\begin{array}{l}\text { Bercerita menggunakan kata ganti aku, saya, kamu, dia, } \\
6\end{array}$ & mereka. \\
\hline 7 & Mau mengungkapkan pendapat secara sederhana. & $18,19,20,21,22$ \\
\hline \multirow{2}{*}{8} & $\begin{array}{l}\text { Mendengarkan dan menceritakan kembali cerita } \\
\text { secara urut. }\end{array}$ & 23,24 \\
\hline & Jumlah & 25 \\
\hline
\end{tabular}

Sumber: Permendiknas No. 58 tahun 2009

Tabel 3.2

Skala Kemampuan Berbicara II

\begin{tabular}{clc}
\hline No & \multicolumn{1}{c}{ Indikator } & Item \\
\hline 1 & Menjawab pertanyaan tentang keterangan / informasi & $1,2,3$, \\
\hline 2 & $\begin{array}{l}\text { Menggunakan dan dapat menjawab pertanyaan apa, } \\
\text { mengapa, dimana, berapa, dsb. }\end{array}$ & $4,5,6,7$ \\
\hline 3 & Berani bertanya secara sederhana & 8,9 \\
\hline 4 & Menceritakan pengalaman/ kejadian secara sederhana. & $10,11,12,13$ \\
\hline 5 & Memberikan keterangan/ informasi tentang sesuatu hal. & $14,15,16,17$ \\
\hline \multirow{2}{*}{6} & $\begin{array}{l}\text { Bercerita menggunakan kata ganti aku, saya, kamu, dia, } \\
\text { mereka. }\end{array}$ & $18,19,20,21,22$ \\
\hline 7 & Mau mengungkapkan pendapat secara sederhana. & 23,24 \\
\hline \multirow{2}{*}{8} & $\begin{array}{l}\text { Mendengarkan dan menceritakan kembali cerita } \\
\text { secara urut. }\end{array}$ & 25 \\
\hline & & $\mathbf{2 5}$ \\
\hline
\end{tabular}

Sumber: Permendiknas No. 58 tahun 2009

\section{HASIL}

\section{Sejarah Sekolah TK Negeri Pembina 2 Pekanbaru}

TK Negeri Pembina 2 komplek damai langgeng beralamatkan di Jalan Soekarno- Hatta Komplek Damai Langgeng Kelurahan.Sidomulyo Barat Kecamatan.Tampan. TK Negeri Pembina 2 berdiri pada tahun 1999 yang dulu gedungnya hanya ada 4 lokal, diantaranya; 1 Ruang kantor, 1 Aula, 2 Ruang kelas. Dengan bertambah banyaknya siswa yang sekolah di TK Negeri Pembina 2, maka pada tahun 2001 TK Negeri Pembina 2 menambahkan lokal atau ruang kelas dari Pemerintah Kota Pekanbaru sebanyak 2 ruang kelas,yang pada masa itu di pimpin oleh seorang kepala sekolah yang bernama $\mathrm{Hj}$. Nirwanis, $\mathrm{S}$. Pd.

Saat ini TK Negeri Pembina 2 Komplek Damai Langgeng mempunyai berbagai macam fasilitas yang sangat baik. Perkembangannya dapat dilihat dari jumlah muridnya yang tiap tahunnya selalu meningkat, begitu juga dengan semakin banyaknya prestasi yang di ukir dan diperoleh baik dari anak maupun dari para guru-guru.Kini TK Negeri Pembina 2 Komplek Damai Langgeng telah terakreditasi dengan nilai "B". 
HASIL

Tabel 4.2

Uji Validitas Instrumen Skala Berbicara I Sebelum Uji Coba Item-Total Statistics

\begin{tabular}{|c|c|c|c|c|}
\hline & $\begin{array}{l}\text { Scale Mean if } \\
\text { Item Deleted }\end{array}$ & $\begin{array}{l}\text { Scale Variance if } \\
\text { Item Deleted }\end{array}$ & $\begin{array}{l}\text { Corrected Item- } \\
\text { Total Correlation }\end{array}$ & $\begin{array}{l}\text { Cronbach's Alpha } \\
\text { if Item Deleted }\end{array}$ \\
\hline item_01 & 60.1000 & 75.433 & .778 & .942 \\
\hline item_02 & 60.2000 & 74.622 & .854 & .942 \\
\hline item_03 & 59.8000 & 79.067 & .624 & .945 \\
\hline item_04 & 60.1000 & 71.211 & .756 & .943 \\
\hline item_05 & 59.8000 & 79.067 & .624 & .945 \\
\hline item_06 & 59.7000 & 82.678 & .000 & .948 \\
\hline item_07 & 59.7000 & 82.678 & .000 & .948 \\
\hline item_08 & 59.9000 & 77.656 & .652 & .944 \\
\hline item_09 & 60.5000 & 76.056 & .564 & .945 \\
\hline item_10 & 60.8000 & 69.511 & .849 & .941 \\
\hline item_11 & 60.8000 & 70.178 & .800 & .942 \\
\hline item_12 & 59.7000 & 82.678 & .000 & .948 \\
\hline item_13 & 59.7000 & 82.678 & .000 & .948 \\
\hline item_14 & 59.9000 & 76.767 & .776 & .943 \\
\hline item_15 & 60.1000 & 71.878 & .870 & .941 \\
\hline item_16 & 59.7000 & 82.678 & .000 & .948 \\
\hline item_17 & 59.8000 & 79.067 & .624 & .945 \\
\hline item_18 & 60.5000 & 70.278 & .891 & .940 \\
\hline item_19 & 60.4000 & 70.267 & .850 & .941 \\
\hline item_20 & 60.8000 & 73.511 & .681 & .944 \\
\hline item_21 & 61.3000 & 76.011 & .711 & .943 \\
\hline item_22 & 61.3000 & 75.567 & .545 & .946 \\
\hline item_23 & 60.1000 & 74.544 & .882 & .941 \\
\hline item_24 & 59.8000 & 79.067 & .624 & .945 \\
\hline item_25 & 60.3000 & 76.011 & .711 & .943 \\
\hline
\end{tabular}

Dari tabel 4.2 di atas dapat disimpulkan bahwasannya Sebelum dilakukan sebagai alat ukur, skala penelitian dilakukan iju coba, terdapat $\mathbf{5}$ item yang tidak valid. Adapun struktur skala sebelum diuji cobakan dapat dilihat pada Blue Print dibawah ini : 
Tabel 4.3

Skala Kemampuan Berbicara II Sebelum Diuji Coba

\begin{tabular}{clc}
\hline No & \multicolumn{1}{c}{ Indikator } & Item \\
\hline 1 & Menjawab pertanyaan tentang keterangan / informasi. & $1,2,3,4$ \\
\hline 2 & $\begin{array}{l}\text { Menggunakan dan dapat menjawab pertanyaan apa, } \\
\text { mengapa, dimana, berapa, dsb. }\end{array}$ & $5,6^{*}, 7^{*}, 8,9$ \\
\hline 3 & Berani bertanya secara sederhana & 10,11 \\
\hline 4 & Menceritakan pengalaman/ kejadian secara sederhana. & $12^{*}, 13^{*}, 14$ \\
\hline 5 & Memberikan keterangan/ informasi tentang sesuatu hal & $15,16^{*}, 17$ \\
\hline \multirow{2}{*}{6} & $\begin{array}{l}\text { Bercerita menggunakan kata ganti aku, saya, kamu, dia, } \\
\text { mereka. }\end{array}$ & $18,19,20,21,22$ \\
\hline 7 & Mau mengungkapkan pendapat secara sederhana. & 23,24 \\
\hline 8 & Mendengarkan dan menceritakan kembali cerita secara urut. & 25 \\
\hline & Jumlah & $\mathbf{2 5}$ \\
\hline
\end{tabular}

Keterangan :

a. Item yang bertanda * adalah item yang tidak valid

$b$. Item yang tidak diberi tanda adalah item valid

Tabel 4.4

Uji Validitas Instrumen Skala Berbicara II Sebelum Uji Coba Item-Total Statistics

\begin{tabular}{lcccc}
\hline & $\begin{array}{c}\text { Scale Mean if } \\
\text { Item Deleted }\end{array}$ & $\begin{array}{c}\text { Scale Variance if } \\
\text { Item Deleted }\end{array}$ & $\begin{array}{c}\text { Corrected Item- } \\
\text { Total Correlation }\end{array}$ & $\begin{array}{c}\text { Cronbach's Alpha if } \\
\text { Item Deleted }\end{array}$ \\
\hline item_01 & 61.5000 & 58.278 & .794 & .934 \\
item_02 & 61.3000 & 63.567 & .000 & .940 \\
item_03 & 61.5000 & 58.722 & .722 & .935 \\
item_04 & 61.4000 & 60.489 & .605 & .937 \\
item_05 & 61.6000 & 56.489 & .943 & .931 \\
item_06 & 61.3000 & 63.567 &. $\mathbf{0 0 0}$ & .940 \\
item_07 & 61.3000 & 63.567 & .000 & .940 \\
item_08 & 62.4000 & 56.267 & .610 & .937 \\
item_09 & 62.5000 & 54.944 & .877 & .931 \\
item_10 & 61.5000 & 59.611 & .580 & .936 \\
item_11 & 61.8000 & 54.622 & .808 & .933 \\
item_12 & 61.3000 & 63.567 & .000 & .940 \\
item_13 & 61.3000 & 63.567 &. $\mathbf{0 0 0}$ & .940 \\
item_14 & 61.3000 & 63.567 & $\mathbf{. 0 0 0}$ & .940 \\
item_15 & 61.4000 & 60.489 & .605 & .937 \\
item_16 & 61.4000 & 60.489 & .605 & .937 \\
item_17 & 62.6000 & 55.378 & .770 & .933 \\
item_18 & 61.8000 & 53.733 & .731 & .935 \\
item_19 & 61.8000 & 53.956 & .877 & .931 \\
item_20 & 62.5000 & 55.389 & .826 & .932
\end{tabular}




\begin{tabular}{lllll} 
item_21 & 62.4000 & 53.378 & .895 & .931 \\
item_22 & 62.8000 & 56.622 & .606 & .937 \\
item_23 & 61.5000 & 59.611 & .580 & .936 \\
item_24 & 61.3000 & 63.567 & .000 & .940 \\
item_25 & 61.7000 & 54.900 & .789 & .933 \\
\hline
\end{tabular}

Sumber: Hasil Olah Data SPSS 17.0

Dari table 4.4 di atas dapat disimpulkan bahwasannya Sebelum dilakukan sebagai alat ukur, skala penelitian dilakukan uji coba, terdapat 7 item yang tidak valid.Adapun struktur skala sebelum diuji cobakan dapat dilihat pada Blue Print dibawah ini :

Tabel 4.5

Skala Kemampuan Berbicara II Sebelum Diuji Coba

\begin{tabular}{clc}
\hline No & \multicolumn{1}{c}{ Indikator } & Item \\
\hline 1 & Menjawab pertanyaan tentang keterangan/ informasi & $1,2^{*}, 3$, \\
\hline 2 & $\begin{array}{l}\text { Menggunakan dan dapat menjawab pertanyaan apa, } \\
\text { mengapa, dimana, berapa, dsb. }\end{array}$ & $4,5,6^{*}, 7^{*}$ \\
\hline 3 & Berani bertanya secara sederhana & 8,9 \\
\hline 4 & Menceritakan pengalaman/ kejadian secara sederhana. & $10,11,12^{*}, 13^{*}$ \\
\hline 5 & Memberikan keterangan/ informasi tentang sesuatu hal. & $14^{*}, 15,16,17$ \\
\hline \multirow{2}{*}{6} & $\begin{array}{l}\text { Bercerita menggunakan kata ganti aku, saya, kamu, dia, } \\
\text { mereka. }\end{array}$ & $18,19,20,21,22$ \\
\hline 7 & Mau mengungkapkan pendapat secara sederhana. & $23,24^{*}$ \\
\hline 8 & Mendengarkan dan menceritakan kembali cerita secara urut. & 25 \\
\hline & Jumlah & 25 \\
\hline
\end{tabular}

Keterangan :

a. Item yang bertanda * adalah item yang tidak valid

b. Item yang tidak diberi tanda adalah item valid

Tabel 4.6

Uji Validitas Instrumen Skala Berbicara I Setelah Uji Coba Item-Total Statistics

Scale Mean if Scale Variance if Corrected Item-Total Cronbach's Alpha Item Deleted Item Deleted Correlation if Item Deleted

\begin{tabular}{lllll}
\hline item_01 & 45.1000 & 75.433 & .778 & .953 \\
item_02 & 45.2000 & 74.622 & .854 & .952 \\
item_03 & 44.8000 & 79.067 & .624 & .956 \\
item_04 & 45.1000 & 71.211 & .756 & .954 \\
item_05 & 44.8000 & 79.067 & .624 & .956 \\
item_06 & 44.9000 & 77.656 & .652 & .955 \\
item_07 & 45.5000 & 76.056 & .564 & .956 \\
item_08 & 45.8000 & 69.511 & .849 & .952 \\
item_09 & 45.8000 & 70.178 & .800 & .953
\end{tabular}




\begin{tabular}{ccccc} 
item_10 & 44.9000 & 76.767 & .776 & .954 \\
item_11 & 45.1000 & 71.878 & .870 & .952 \\
item_12 & 44.8000 & 79.067 & .624 & .956 \\
item_13 & 45.5000 & 70.278 & .891 & .951 \\
item_14 & 45.4000 & 70.267 & .850 & .952 \\
item_15 & 45.8000 & 73.511 & .681 & .955 \\
item_16 & 46.3000 & 76.011 & .711 & .954 \\
item_17 & 46.3000 & 75.567 & .545 & .957 \\
item_18 & 45.1000 & 74.544 & .882 & .952 \\
item_19 & 44.8000 & 79.067 & .624 & .956 \\
item_20 & 45.3000 & 76.011 & .711 & .954 \\
\hline Sumber: Hasil Olah Data SPSS 17.0 & & &
\end{tabular}

Dari tabel 4.6 di atas dapat disimpulkan bahwasannya Uji coba kedua skala diatas dilakukan untuk menetapkan Validitas dan Reliabilitas Instrumen. Instrumen penelitian dikatakan Valid apabila taraf diskriminasi item $\geq 0,30$, sedangkan taraf Reliabilitas Instrumen $\geq 0,70$ (Saifudin Azwar: 2000). Adapun struktur skala setelah dilakukan uji coba instrument penelitian dapat dilihat pada Blue Print sebagai berikut :

Tabel 4.7

Skala Kemampuan Berbicara I Setelah Diuji Coba

\begin{tabular}{clc}
\hline No & \multicolumn{1}{c}{ Indikator } & Item \\
\hline 1 & Menjawab pertanyaan tentang keterangan / informasi & $1,2,3,4$ \\
\hline \multirow{2}{*}{2} & $\begin{array}{l}\text { Menggunakan dan dapat menjawab pertanyaan apa, mengapa, } \\
\text { dimana, berapa, dsb. }\end{array}$ & $5,6,7$ \\
\hline 3 & Berani bertanya secara sederhana & 8,9 \\
\hline 4 & Menceritakan pengalaman/ kejadian secara sederhana. & 10 \\
\hline 5 & Memberikan keterangan/ informasi tentang sesuatu hal. & 11,12 \\
\hline \multirow{2}{*}{6} & $\begin{array}{l}\text { Bercerita menggunakan kata ganti aku, saya, kamu, dia, } \\
\text { mereka. }\end{array}$ & $13,14,15,16$, \\
\hline 7 & Mau mengungkapkan pendapat secara sederhana. & 17 \\
\hline 8 & Mendengarkan dan menceritakan kembali cerita secara urut. & 18,19 \\
\hline & Jumlah & $\mathbf{2 0}$ \\
\hline
\end{tabular}

Tabel 4.8

Uji Validitas Instrumen Skala Berbicara II Setelah Uji Coba

\begin{tabular}{lcccc}
\hline & $\begin{array}{c}\text { Scale Mean if } \\
\text { Item Deleted }\end{array}$ & $\begin{array}{c}\text { Scale Variance if } \\
\text { Item Deleted }\end{array}$ & $\begin{array}{c}\text { Corrected Item-Total } \\
\text { Correlation }\end{array}$ & $\begin{array}{c}\text { Cronbach's Alpha } \\
\text { if Item Deleted }\end{array}$ \\
\hline item_01 & 40.5000 & 58.278 & .794 & .951 \\
item_02 & 40.5000 & 58.722 & .722 & .952 \\
item_03 & 40.4000 & 60.489 & .605 & .954 \\
item_04 & 40.6000 & 56.489 & .943 & .948
\end{tabular}




\begin{tabular}{lllll} 
item_05 & 41.4000 & 56.267 & .610 & .954 \\
item_06 & 41.5000 & 54.944 & .877 & .948 \\
item_07 & 40.5000 & 59.611 & .580 & .953 \\
item_08 & 40.8000 & 54.622 & .808 & .950 \\
item_09 & 40.4000 & 60.489 & .605 & .954 \\
item_10 & 40.4000 & 60.489 & .605 & .954 \\
item_11 & 41.6000 & 55.378 & .770 & .950 \\
item_12 & 40.8000 & 53.733 & .731 & .952 \\
item_13 & 40.8000 & 53.956 & .877 & .948 \\
item_14 & 41.5000 & 55.389 & .826 & .949 \\
item_15 & 41.4000 & 53.378 & .895 & .948 \\
item_16 & 41.8000 & 56.622 & .606 & .954 \\
item_17 & 40.5000 & 59.611 & .580 & .953 \\
item_18 & 40.7000 & 54.900 & .789 & .950 \\
\hline
\end{tabular}

Sumber: Hasil Olah Data SPSS 17.0

Dari table 4.8 di atas dapat disimpulkan bahwasannya setelah dilakukan sebagai alat ukur, skala penelitian dilakukan uji coba dan semua item Valid. Adapun struktur skala setelah dilakukan uji coba instrument penelitian dapat dilihat pada Blue Print sebagai berikut :

Tabel 4.9

Skala Kemampuan Berbicara II Setelah Diuji Coba

\begin{tabular}{llc}
\hline No & \multicolumn{1}{c}{ Indikator } & Item \\
\hline 1 & Menjawab pertanyaan tentang keterangan / informasi & 1,2 \\
\hline 2 & $\begin{array}{l}\text { Menggunakan dan dapat menjawab pertanyaan apa, mengapa, } \\
\text { dimana, berapa, dsb. }\end{array}$ & $4,5,6$ \\
\hline 3 & Berani bertanya secara sederhana & 6,7 \\
\hline 4 & Menceritakan pengalaman/ kejadian secara sederhana. & 8,9 \\
\hline 5 & Memberikan keterangan/ informasi tentang sesuatu hal. & $10,11,12$ \\
\hline 6 & Bercerita menggunakan kata ganti aku, saya, kamu, dia, mereka. & $13,14,15,16$ \\
\hline 7 & Mau mengungkapkan pendapat secara sederhana. & 17 \\
\hline 8 & Mendengarkan dan menceritakan kembali cerita secara urut. & 18 \\
\hline & Jumlah & $\mathbf{1 8}$ \\
\hline
\end{tabular}

Setelah dilakukan uji coba pada skala I dari 25 item yang gugur adalah nomor $6,7,12,13,16$ dengan demikian item yang tersisa sebanyak 20 item. Pada skala II dari 25 item yang gugur adalah nomor 2,6, 7, 12, 13, 14, 24 dengan demikian item yang tersisa adalah 18 item.Uji validitas dan reliabilitas ini menggunakan computer program SPSS versi 17.0 for windows.

Catatan :Uji coba yang dipakai adalah Uji Coba Terpakai artinya Data Total hasil Uji Coba dipakai sekaligus sebagai data penelitian untuk menjawab Hipotesis (Saifudin Azwar: 2000). 
Reliability Statistics

\begin{tabular}{|c|c|c|c|}
\hline \multirow[t]{6}{*}{ Cronbach's Alpha } & Part 1 & Value & .904 \\
\hline & & $\mathrm{N}$ of Items & $10^{\mathrm{a}}$ \\
\hline & Part 2 & Value & .916 \\
\hline & & $\mathrm{N}$ of Items & $10^{\mathrm{b}}$ \\
\hline & & Total $\mathrm{N}$ of Items & 20 \\
\hline & & Correlation Between Forms & .973 \\
\hline \multirow{3}{*}{$\begin{array}{l}\text { Spearman-Brown } \\
\text { Coefficient }\end{array}$} & & Equal Length & .986 \\
\hline & & Unequal Length & .986 \\
\hline & & Guttman Split-Half Coefficient & .986 \\
\hline
\end{tabular}

Sumber: Hasil Olah Data SPSS 17.0

Berdasarkan hasil uji coba reliabilitas, tampak nilai Cronbach's Alpha sebesar 0.973. Menurut Sakara (2000) hasil uji reliabitas dianggap reliable jika nilaii cronbach alpha $\geq 0,6$. Berdasarkan pedoman tersebut maka instrument penelitian tersebut Reliable.

\section{Hasil Uji Wilcoxon Signed Ranks Test}

Tabel 4.11

Hasil Uji Wilcoxon Signed Ranks Test

Test Statistics ${ }^{b}$

\begin{tabular}{lr}
\hline & bicara2 - bicara1 \\
\hline $\mathrm{Z}$ & $-2.719^{\mathrm{a}}$ \\
Asymp. Sig. (2-tailed) & .007 \\
\hline
\end{tabular}

a. Based on positive ranks.

b. Wilcoxon Signed Ranks Test

Jadi berdasarkan hasil analisis maka ditemukan perbedaan kemampuan berbicara anak sebesar 2.719adengan taraf signifikan $\alpha 0.007$. Angka ini adalah dibawah nilai signifikansi yang ditetapkan $(0.007<$
0.05) yang artinya adalah terdapat pengaruh yang signifikan antara kemampuan berbicara anak pada pengukuran skala 1 dan skala II disebabkan oleh treatment/perlakuan metode bermain peran makro. 


\section{PEMBAHASAN}

Berdasarkan hasil analisis maka ditemukan pengaruh kemampuan berbicara anak sebesar $-2.719^{a}$ dengan taraf signifikan $\boldsymbol{\alpha} \mathbf{0 . 0 0 7}$. Angka ini adalah dibawah nilai signifikansi yang ditetapkan $(0.007<0.05)$ yang artinya adalah terdapat pengaruh yang signifikan antara kemampuan berbicara anak pada pengukuran skala 1 dan skala II disebabkan oleh treatment/perlakuan metode bermain peran makro.Hal ini sesuai dengan rumusan masalah dalam penelitian maka diperoleh hipotesisnya adalah "Terdapat Pengaruh Metode Bermain Peran Makro Terhadap Peningkatan Kemampuan Berbicara Anak Usia 5-6 Tahun Di TK Negeri Pembina 2 Pekanbaru".

Dari jumlah sampel 10 orang anak yang diberi dua perlakuan dengan rata-rata (Mean Rank) $=6.00$. Dalam artian anak yang diberi perlakuan metode bermain peran makro memiliki nilai rata-rata yang signifikan, hal ini dapat dilihat dari hasil pengamatan, yaitu: (1) Anak dapat menjawab pertanyaan tentang keterangan/ informasi; (2) Anak dapat menggunakan dan dapat menjawab pertanyaan apa, mengapa, dimana, berapa, dsb; (3) Anak berani bertanya secara sederhana; (4) Anak dapat men-ceritakan pengalaman/ kejadian secara sederhana; (5) Anak dapat memberikan keterangan/ informasi tentang sesuatu hal; (6) Anak dapat bercerita menggunakan kata ganti aku, saya, kamu, dia, mereka; (7)Anak mau mengungkapkan pendapat secara sederhana; dan (8) Anak mendengarkan dan menceritakan kembali cerita secara urut.

Hal ini menjawab rumusan masalah apakah terdapat pengaruh metode bermain peran makro terhadap peningkatan kemampuan berbicara anak. Dengan bermain peran, anak akan diberi kesempatan untuk menggam- barkan, mengungkapkan atau mengekspresikan suatu sikap, tingkah laku atau penghayatan sesuatu yang dipikirkan, dirasakan, atau diinginkan seandainya ia menjadi tokoh yang sedang diperankannya itu.

Dalam hal ini anak dapat mengekspresikan gerakan dan dapat mengendalikan emosinya, bisa menunjukkan rasa marah, takut, senang dan gembira.

Metode bermain peran dikategorikan sebagai metode mengajar yang berumpun kepada metode perilaku yang diterapkan dalam pengajaran. Karakteristiknya adalah adanya kecenderungan memecahkan tugas belajar dalam sejumlah perilaku yang berurutan, konkret dan dapat diamati (Nurbiana Dhieni, 2006:7.31).

Diperkuat lagi dengan toeri menurut Vygotsky dan Erikson (dalam Diana Mutiah, 2010:115) bermain peran makro adalah anak bermain peran sesungguhnya dan menjadi seseorang atau sesuatu. Saat anak memiliki pengalaman sehari-hari dengan main peran makro dengan tema sekitar kehidupan nyata, mereka belajar banyak keterampilan pra-akademis seperti mendengarkan, menyelesaikan masalah dan bermain kerja sama dengan yang lain.

Kemampuan berbicara merupakan kemampuan anak untuk berkomunikasi secara lisan dengan orang lain. Kemampuan ini memberikan gambaran tentang kesanggupan anak menyusun berbagai kosa kata yang telah dikuasai menjadi suatu rangkaian pembicaraan secara berstruktur (Depdiknas, 2007:15).

Kemudian Nurbiana Dhieni (2006: 39) menyatakan bahwa pada anak usia TK (4-6 tahun) kemampuan berbahasa anak yang paling efektif adalah kemampuan berbicara. Hal ini ternyata selaras dengan karakteristik 
umum kemampuan bahasa anak pada usia tersebut. Kemampuan ini meliputi kemampuan anak untuk dapat berbicara dengan baik, melaksanakan tiga perintah lisan secara berurutan dengan benar, mendengarkan dan menceritakan kembali cerita sederhana dengan urutan yang mudah dipahami, menyebutkan nama, jenis kelamin dan umurnya, menggunakan kata sambung seperti dan, karena, tetapi, menggunakan kata tanya seperti bagaimana, apa, mengapa, kapan, membandingkan dua hal, memahami konsep timbal balik, menyusun kalimat, mengucapkan lebih dari tiga kalimat, dan mengenali tulisan sederhana.

\section{SIMPULAN}

Berdasarkan hasil pengujian hipotesis dan penelitian maka peneliti menyimpulkan bahwa pengaruh metode bermain peran makro terhadap peningkatan kemampuan berbicara anak usia 5-6 tahun di Taman KanakKanak Negeri Pembina 2 Pekanbaru adalah Signifikan. Hasil pengujian hipotesisnya menunjukkan bahwa hipotesis penelitian (Ha) yang diajukan dalam penelitian ini diterima. Variabel $\mathrm{X}$ dalam penelitian ini adalah Metode Bermain Peran Makro dan variabel Y Kemampuan Berbicara Anak.

Berdasarkan uraian penelitian dan pembahasan yang telah diuraikan pada bab IV, kesimpulannya dapat dirumuskan sebagai berikut "Terdapat Pengaruh Metode Bermain Peran Makro Terhadap Peningkatan Kemampuan Berbicara Anak Usia 5-6 Tahun di Taman Kanak-Kanak Negeri Pembina 2 Pekanbaru". Hal ini terlihat dari hasil pengukuran pada skala berbicara I dan skala berbicara II dengan analisis uji Wilcixon yang mana Nilai Asymp. Sig $(0.007=0.07 \%)<\alpha=5 \%$, yang artinya signifikan yaitu menolak $\boldsymbol{H}_{0}$ dan menerima $\mathrm{H}_{a}$.

Fasilitas pendukung kegiatan bermain peran sangat mempengaruhi anak dalam memerankan tokoh-tokoh karakter yang dimainkan sehingga mereka dapat melakukan perannya dengan total dan penuh penghayatan.

\section{DAFTAR RUJUKAN}

Ahmadi, Abu dan Pasetya, Joko Tri. 2005. Strategi Belajar Mengajar. Bandung: Pustaka Setia.

Arikunto, Suharsimi. 1998. Prosedur Penelitian Suatu Pendekatan Praktek. Jakarta: Rineka Cipta.

Azwar, Saifudin. 2012. Penyusunan Skala Psikologi.Yogyakarta: Pustaka Pelajar.

Dhieni, Nurbiana. 2006. Metode Pengembangan Bahasa. Jakarta: Univertas Terbuka.

Gunarti, Winda et. al., 2008. Metode Pengembangan Prilaku dan Kemampuan Dasar Anak Usia Dini. Jakarta: Universitas Terbuka.

Henry, Tarigan G., 2008. Berbicara Sebagai Suatu Keterampilan Berbahasa. Bandung: Angkasa.

Herawati, Netti. 2005. Buku Pendidikkan Anak Usia Dini. Quantum: Pekanbaru.

Moeslichatoen. 2004. Metode pengajaran di TK . Jakarta: Rineka Cipta.

Mustafa, et. al., 2006. Keterampilan Berbicara. Padang: FPBS IKIP Padang.

Mutiah, Diana. 2010. Psikologi Bermain Anak Usia Dini. Jakarta: Fajar Interpratama.

Roestiyah. 2001. Strategi Belajar Mengajar. Jakarta: Rineka Cipta.

Sanjaya, Wina. 2007. Strategi Pembelajaran Berorientasi Standar 
Proses Pendidikan. Jakarta: Kencana.

Santosa, et. al., 2006. Materi dan Pembelajaran Bahasa Indonesia SD. Jakarta: Universitas Terbuka.

Sujiono, Yuliani Nurani. 2010. Bermain Kreatif Berbasis Kecerdasan Jamak.Jakarta: Indeks.

Sudijono, Anas. 2010. Pengantar Statistik Pendidikan. Jakarta: Raja Grafindo Persada.
Sudjana, Nana. 2005. Dasar-Dasar Proses Belajar Mengajar. Bandung: Sinar Baru.

Sugiyono. 2013. Metode Penelitian Kuantitatif Kualitatif Dan $R \& D$. Bandung: ALFABETA.

Suhartono. 2005. Pengembangan Keterampilan Bicara Anak Usia Dini. Jakarta. Depdiknas. 